\title{
Modification of the lithospheric mantle during the early activity of a cenozoic plume in the North Tien Shan: Evidence from mantle xenoliths in basalts
}

\author{
A. F. Grachev ${ }^{1}$, P. V. Ermolov ${ }^{2}$, and Yifen $\mathrm{Wang}^{3}$ \\ Received 28 August 2014; accepted 2 September 2014; published 23 September 2014.
}

Data on the composition and the He-Ar and Sm-Nd isotopic systems of ultramafic xenoliths in Cretaceous-Paleogene basalt in the North Tien Shan provide insight into a lateral heterogeneity of the upper mantle. The mantle beneath the northern and southern portions of the North Tien Shan has a lherzolite composition, whereas pyroxenites found east of Lake Issyk Kul were produced by the partial melting of and metasomatism in the primary lherzolite mantle under the effect of a mantle plume at $55 \mathrm{Ma}$. This lateral heterogeneity of the upper mantle is clearly reflected in variations in the velocities of seismic waves and gravity anomalies when the influence of the crust is subtracted, as was determined for the portion of the Tien Shan east of the Talas-Fergana Fault. KEYWORDS: Upper mantle; ultramafic xenoliths; basalts; mantle plume; North Tien Shan.

Citation: Grachev, A. F., P. V. Ermolov, and Yifen Wang (2014), Modification of the lithospheric mantle during the early activity of a cenozoic plume in the North Tien Shan: Evidence from mantle xenoliths in basalts, Russ. J. Earth. Sci., 14, ES2002, doi:10.2205/2014ES000540.

\section{Introduction}

The very first data on the composition of mantle xenoliths in alkaline basalts in the North Tien Shan were published by Dobretsov and Dobretsova 1974, 1979. In the vicinity of Mount Uchkuduk west of Issyk Kul Lake, they have found nodules in volcanic rocks. These nodules composed a practically continuous series from olivinite to pyroxenite. Data obtained by these researchers on the composition of the rockforming minerals led them to conclude that the mantle beneath the North Tien Shan has a predominantly pyroxenite composition [Dobretsov et al., 1979].

In 1990-1991, the Joint Soviet-Chinese Expedition, which included A. F. Grachev (Institute of Physics of the Earth, Russian Academy of Sciences), P. V. Ermolov, A. V. Leonov (Institute of Complex Development of Mineral Resources of the National Academy of Kazakhstan), and Wang Yifen (Institute of Geology, Academy Sinica, China), studied vertical sections of Early Cenozoic volcanics rocks in the North Tien Shan. Xenoliths of ultramafic rocks were found at two localities: in the Kastek and Uchkuduk necks [Ermolov and Wang Yifen, 1997 Grachev, 1999 Wang Yifen and Ermolov, 1992.

\footnotetext{
${ }^{1}$ Institute of Physics of the Earth, Russian Academy of Sciences, Moscow, Russia

${ }^{2}$ Institute of Complex Development of Mineral Resources of the National Academy of Kazakhstan, Karaganda, Kazakhstan

${ }^{3}$ Institute of Geology, Academy Sinica, Beijing, China

Copyright 2014 by the Geophysical Center RAS.

http://elpub.wdcb.ru/journals/rjes/doi/2014ES000540.html
}

The comparative analysis of the composition of these xenoliths led us to detect remarkable compositional variations in the mantle beneath the North Tien Shan: it is likely of predominantly lherzolitic beneath the area of the Kastek neck and pyroxenite underneath Uchkuduk (the distance between the sites is approximately $500 \mathrm{~km}$ ). Mantle xenoliths were later also found in the vicinities of Toyun and Ortosu in the southern Kyrgyz Republic, where the mantle has a lherzolite composition [Bagdassarov et al., 2011] Egorova et al., 2009. Zheng et al., 2006 (Figure 1). It should be mentioned that along with the aforementioned four localities, small xenoliths and olivine megacrysts were found in practically all outcrops of volcanic rocks not only in the Kyrgyz Republic but also elsewhere [Dobretsov and Dobretsova, 1979 1974 Gapeeva, 1949 1951. This publication presents our lately obtained data on mantle xenoliths from the Kastek and Uchkuduk necks. Considered together with literature data, these materials makes it possible to conduct comparative analysis of the composition of the mantle beneath the Central Tien Shan and suggest, on this basis, an explanation for the variations in the velocities of seismic waves in the mantle beneath the North Tien Shan [Vinnik, 2004 Vinnik et al., 1998 2004.

\section{Methods}

The chemical composition of the samples was analyzed by XRF with the application of an original analysis tech- 


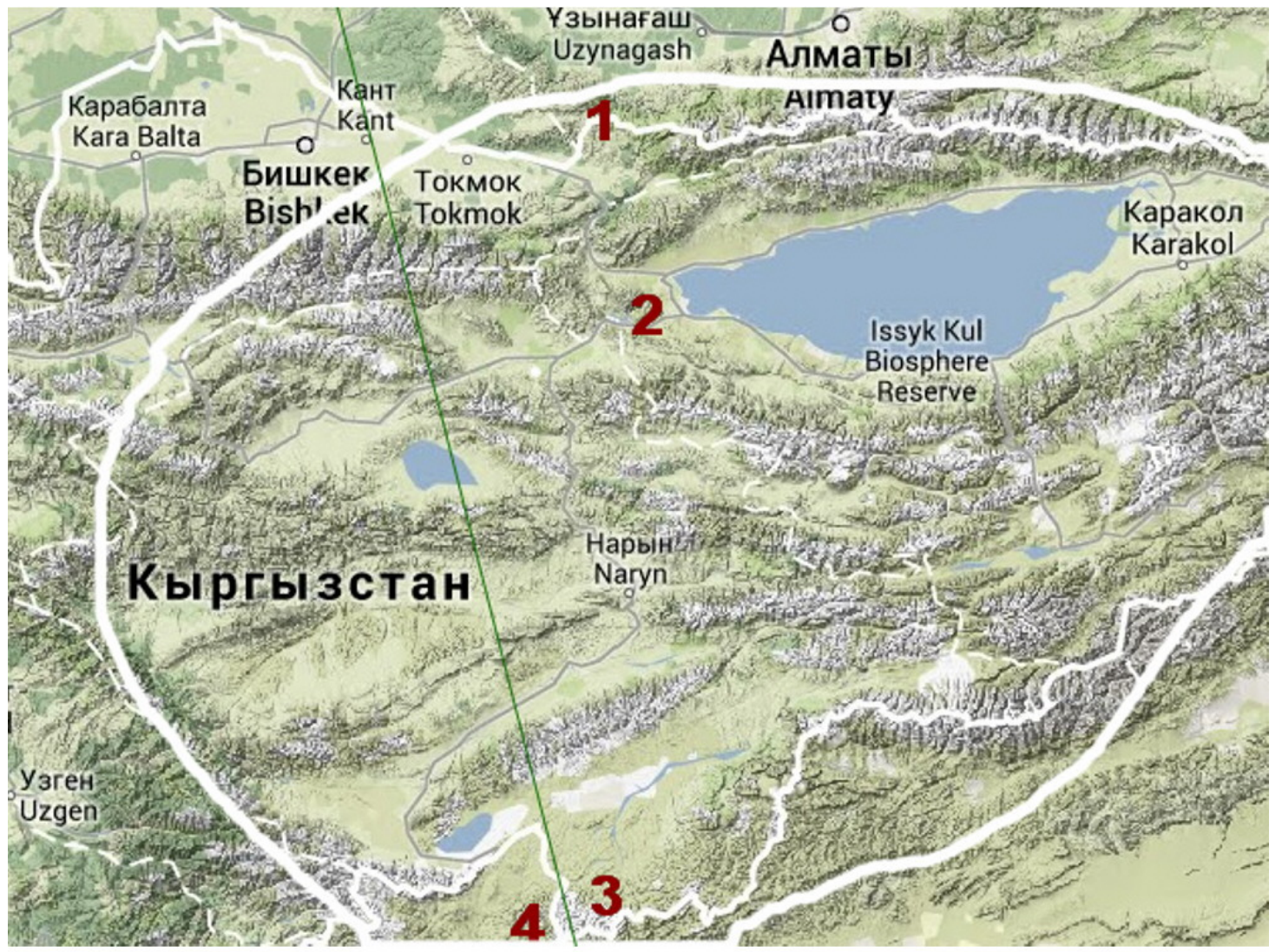

Figure 1. Map indicating the approximate boundaries of the Cretaceous-Paleogene basalts area of the North Tien Shan (thick white line). Ciphers show the places of ultramafic xenoliths sampling: 1 - Kastek, 2 - Uchkuduk, 3 - Ortosu, 4 - Toun. Straight white line is the profile, along which cross-section of the velocity model is shown in Figure 8 along Vinnik et al. 2004.

nique development at Sevzapgeologiya. The analytical XRF setup consisted of a 1000-channel pulse analyzer, spectrometric amplifier, and a $\mathrm{Si}(\mathrm{Li})$ detector with $25 \mathrm{~mm}^{2}$ sensitive area and an energy resolution $(5.9 \mathrm{keV})$ of $210 \mathrm{eV}$. The material to be analyzed (20 g, 200 mesh) was placed into specialized trays. The characteristic radiation was excited by (i) an $\mathrm{X}$ ray tube with an intermediate $\mathrm{Ag}$ target and (ii) the Am-241 radioactive isotope source. The XRF analyses were carried out with the VM, SGD-1A, SG-1A, ST-1A, SA-1, TV, and SGKHM-3 certified standards.

The composition of the rock-forming minerals from the xenoliths was studied using Cameca Camebax electron microprobe with energy-dispersive spectrometer (with a resolution of $160 \mathrm{eV}$ ) at the Karpinsky Russian Geological Research Institute (VSEGEI). The analysis was conducted at $15 \mathrm{kV}$ accelerating voltage and $2 \mathrm{nA}$ beam current. Monomineralic separates were obtained from our samples of ultramafic xenoliths with the use of heavy liquids and the subsequent magnetic separation of minerals. If needed, the concentrates were then $95-99 \%$ purified by hand-picking. Xenolith samples were crushed to $3-5 \mathrm{~cm}$, washed in cold $0.1 \mathrm{NHCl}$ to get rid of surface contaminants, and then pulverized in an agate mortar to 200 mesh grain size. Helium was extracted from rocks and minerals by the melting techniques [Kamensky et al., 1990] and by crushing the samples [Ikorsky and Kamen- sky, 1998 at the Laboratory of Isotopic Geochronology of the Institute of Precambrian Geology and Geochronology, Russian Academy of Sciences. The crushing technique makes it possible to selectively extract gases from fluid inclusions and thus to minimize the effect of radiogenic gases accumulated in the crystal structure of minerals [Kaneoka, 1998].

To extract gases, $0.16-2.25 \mathrm{~g}$ of the material and steel rolling crushers were placed in a glass ampoule, which was then evacuated and welded. The material was crushed due to vibrations of the ampoule. The He isotopic composition and concentration were measured on a MI-1201 no. 22-78 mass spectrometer with a He detection limit of $5 \times 10^{-5} \mathrm{~A} /$ torr. The concentrations were calculated from the height of the peak accurate to $5 \%( \pm 1 \sigma)$, and the errors of the measured isotopic ratios were $\pm 20 \%$ at ${ }^{3} \mathrm{He} /{ }^{4} \mathrm{He}$ of $n \times 10^{-8}$ and $\pm 2 \%$ at ${ }^{3} \mathrm{He} /{ }^{4} \mathrm{He}$ of $n \times 10^{-6}$. The blanks were conducted after reloading the cassette under the same conditions as the analyses of the samples. Sm, Nd, Rb, and $\mathrm{Sr}$ were extracted for isotopic analysis at the same institute in compliance with the method described in [Richard et al., 1976]. The blanks were $0.003 \mathrm{ng}$ for $\mathrm{Rb}, 0.2 \mathrm{ng}$ for $\mathrm{Sr}, 0.03 \mathrm{ng}$ for $\mathrm{Sm}$, and $0.08 \mathrm{ng}$ for $\mathrm{Nd}$. The isotopic composition of these elements was determined on an Finnigan MAT-261 8-collector mass spectrometer in static mode, with the simultaneous recording of the ion currents of various isotopes of elements. 
Table 1. Whole-Rock Composition (wt. \%) of the Mantle Xenoliths From Basalts

\begin{tabular}{|c|c|c|c|c|c|c|c|c|c|}
\hline & 1 & 2 & 3 & 4 & 5 & 6 & 7 & 8 & 9 \\
\hline $\mathrm{SiO}_{2}$ & 46.70 & 45.70 & 44.90 & 45.10 & 45.30 & 45.37 & 45.10 & 47.40 & 49.30 \\
\hline $\mathrm{TiO}_{2}$ & 0.10 & 0.04 & 0.05 & 0.02 & 0.04 & 0.13 & 0.03 & 0.46 & 0.10 \\
\hline $\mathrm{Al}_{2} \mathrm{O}_{3}$ & 4.50 & 3.50 & 3.55 & 1.30 & 3.05 & 3.76 & 1.20 & 3.45 & 1.55 \\
\hline $\mathrm{FeOt}$ & 8.29 & 8.75 & 8.48 & 8.49 & 8.17 & 8.14 & 8.41 & 6.64 & 7.59 \\
\hline $\mathrm{MnO}$ & - & - & - & - & - & 0.18 & - & 0.15 & 0.18 \\
\hline $\mathrm{MgO}$ & 36.13 & 38.35 & 39.14 & 44.29 & 40.38 & 36.86 & 43.46 & 17.97 & 26.58 \\
\hline $\mathrm{CaO}$ & 2.07 & 2.34 & 2.39 & 0.36 & 1.55 & 3.00 & 0.51 & 12.47 & 13.38 \\
\hline $\mathrm{Na}_{2} \mathrm{O}$ & 0.17 & 0.10 & 0.05 & 0.13 & 0.17 & 0.22 & 0.05 & 0.95 & 0.15 \\
\hline $\mathrm{K}_{2} \mathrm{O}$ & 0.13 & 0.05 & 0.05 & 0.05 & 0.05 & 0.04 & 0.05 & 0.17 & 0.05 \\
\hline $\mathrm{P}_{2} \mathrm{O}_{5}$ & 0.07 & 0.07 & 0.07 & 0.07 & 0.07 & 0.02 & 0.07 & 0.07 & 0.07 \\
\hline \multirow[t]{2}{*}{ Total } & 98.16 & 98.90 & 98.68 & 99.81 & 98.77 & 98.71 & 98.88 & 99.72 & 98.95 \\
\hline & 10 & 11 & 12 & 13 & 14 & 15 & 16 & 17 & 18 \\
\hline $\mathrm{SiO}_{2}$ & 44.40 & 49.00 & 42.30 & 42.00 & 44.80 & 44.30 & 45.10 & 45.96 & 45.83 \\
\hline $\mathrm{TiO}_{2}$ & 0.40 & 1.06 & 0.54 & 0.44 & 1.70 & 2.06 & 1.86 & 0.18 & 0.20 \\
\hline $\mathrm{Al}_{2} \mathrm{O}_{3}$ & 6.05 & 5.65 & 3.30 & 3.25 & 7.85 & 9.85 & 9.15 & 4.06 & 5.29 \\
\hline $\mathrm{FeOt}$ & 13.16 & 11.81 & 14.73 & 16.02 & 10.33 & 9.81 & 7.87 & 7.54 & 8.90 \\
\hline $\mathrm{MnO}$ & 0.19 & 0.23 & 0.22 & 0.24 & 0.14 & 0.18 & 0.13 & 0.13 & 0.13 \\
\hline $\mathrm{MgO}$ & 23.27 & 14.31 & 30.46 & 30.81 & 16.56 & 13.16 & 13.36 & 37.78 & 35.51 \\
\hline $\mathrm{CaO}$ & 10.69 & 16.42 & 6.20 & 4.73 & 14.56 & 15.77 & 17.74 & 3.21 & 4.01 \\
\hline $\mathrm{Na}_{2} \mathrm{O}$ & 0.85 & 0.75 & 0.45 & 0.27 & 0.85 & 1.57 & 1.10 & 0.33 & 0.12 \\
\hline $\mathrm{K}_{2} \mathrm{O}$ & 0.05 & 0.17 & 0.05 & 0.05 & 0.10 & 0.18 & 0.18 & 0.03 & 0.06 \\
\hline $\mathrm{P}_{2} \mathrm{O}_{5}$ & 0.11 & 0.07 & 0.08 & 0.08 & 0.14 & 0.18 & 0.11 & & \\
\hline Total & 99.17 & 99.47 & 98.33 & 97.99 & 97.03 & 97.06 & 97.40 & & \\
\hline
\end{tabular}

Note: 1-9 - Kastek, 10-16 - Uchkydyk, 17 - primitive mantle [Zindler and Hart, 1986], 18 - the same [Grachev, 1999].

\section{Ultramafic Nodules From the Kastek Neck}

In 1973, A. I. Radchenko and F. M. Ibragimov have mapped an olivine basalt neck in the Kastek Range. The neck contained lherzolite nodules and rare eclogite xenoliths, and it was later suggested that the rocks are of "kimberlite nature" and could likely be diamondiferous [Radchenko, 1995. Simultaneously with the find of an olivine basalt neck in the Kastek Range, dikes and small volcanic bodies of analogous composition, which contained minerals accompanying diamond, and two "diatremes" (Ovchinnikova and Karagaily), which contained minute diamond grains, were discovered [Radchenko, 1995].

The Kastek neck, which is exposed over an area of $400 \mathrm{~m}^{2}$ in the northern face of the Kastek Range west of the village of Uzunagach, in the upper reaches of the Kastek River, at an elevation of 2290.1, cuts across red Paleozoic beds, whose exact age is uncertain. Inasmuch as the neck is poorly exposed, mining operations were conducted in order to make it possible to collect representative samples of fresh xenoliths and megacrysts in the basalts, as is particularly important when He isotopic composition is studied.

The xenoliths range from $3-5$ to $15-20 \mathrm{~cm}$ across, their morphologies vary from flattened to angular, and their contacts with the host basalt are sharp. The textures of the rocks are protogranular. According to their modal compo- sition, the xenoliths are strongly dominated by spinel and garnet-spinel lherzolite, while websterite and pyroxenite are rare.

The lherzolite xenoliths of the so-called green suite are noted for high $\mathrm{Al}_{2} \mathrm{O}_{3}$ and $\mathrm{CaO}$ contents at relatively low $\mathrm{MgO}$ concentrations, which makes them somewhat close in composition to the primitive mantle Table 1 compare with columns 17 and 18). The occurrence of garnet suggests that the xenoliths were brought from depths of 60-70 km, which corresponds to the transition from the spinel to garnet depth facies.

The mineralogical composition of the rocks is typical of the garnet-spinel facies of the lherzolite mantle: $40-50 \%$ olivine, $15-40 \%$ clinopyroxene, $10-30 \%$ orthopyroxene, and accessory spinel and garnet.

The olivine shows relatively narrow compositional variations (the average concentration of the forsterite end member is close to $80 \%$, Table 2 , columns 1-9), whereas olivine in the host basalt has the composition $\mathrm{Fo}_{79}-\mathrm{Fo}_{80}$ [Grachev, 1999 . The Ca-rich pyroxene belongs to the Cr-diopside series, and the Ca-poor pyroxene is enstatite (Table 3 , Table 4). The spinel is brown and rich in $\mathrm{Al}$ and $\mathrm{Fe}$ (picotite, Table 5). The composition of pyroxene in the host basalts (megacrysts and phenocrysts) is close to those of clinopyroxene in lherzolites, with the only difference in $\mathrm{Mg \#}$.

The composition of the garnet is of particular interest Table 6): it is pyrope-almandine, as is typical of ultramafic 
Table 2. Electron Microprobe Analyses (wt. \%) of Olivines From the Kastek and Uchkuduk Xenoliths

\begin{tabular}{|c|c|c|c|c|c|c|c|c|c|}
\hline & 1 & 2 & 3 & 4 & 5 & 6 & 7 & 8 & 9 \\
\hline $\mathrm{SiO}_{2}$ & 40.13 & 40.84 & 41.48 & 40.96 & 41.61 & 41.06 & 41.52 & 41.57 & 41.98 \\
\hline $\mathrm{Al}_{2} \mathrm{O}_{3}$ & - & 0.60 & 0.38 & - & - & 0.87 & 0.88 & 0.86 & 1.05 \\
\hline $\mathrm{FeOt}$ & 10.26 & 10.27 & 10.21 & 10.11 & 10.25 & 10.11 & 9.41 & 9.69 & 9.90 \\
\hline $\mathrm{MnO}$ & 0.33 & - & - & - & - & - & - & - & - \\
\hline $\mathrm{MgO}$ & 48.03 & 48.28 & 48.18 & 48.98 & 48.38 & 48.16 & 47.03 & 47.48 & 47.50 \\
\hline $\mathrm{CaO}$ & - & 0.13 & - & - & - & - & 0.15 & - & - \\
\hline $\mathrm{Fa}$ & 5.99 & 10.66 & 10.63 & 10.38 & 10.63 & 10.54 & 10.09 & 10.27 & 10.47 \\
\hline \multirow[t]{2}{*}{ Fo } & 89.34 & 89.37 & 89.62 & 89.37 & 89.46 & 89.91 & 89.73 & 89.53 & 89.55 \\
\hline & 10 & 11 & 12 & 13 & 14 & 15 & 16 & 17 & 18 \\
\hline $\mathrm{SiO}_{2}$ & 38.99 & 39.83 & 39.74 & 40.09 & 39.85 & 39.19 & 39.79 & 37.30 & 37.41 \\
\hline $\mathrm{FeOt}$ & 17.08 & 16.93 & 16.82 & 16.48 & 17.04 & 21.20 & 21.10 & 23.77 & 20.21 \\
\hline $\mathrm{MnO}$ & 0.52 & 0.43 & 0.35 & 0.45 & - & 0.58 & 0.50 & 0.47 & - \\
\hline $\mathrm{MgO}$ & 43.44 & 42.91 & 43.33 & 43.12 & 42.79 & 38.85 & 38.83 & 38.05 & 42.29 \\
\hline $\mathrm{CaO}$ & - & - & - & - & 0.21 & 0.25 & - & 0.31 & - \\
\hline $\mathrm{Fa}$ & 17.45 & 18.50 & 18.02 & 18.06 & 18.26 & 23.93 & 23.79 & 24.31 & 17.37 \\
\hline Fo & 82.55 & 81.80 & 81.98 & 81.94 & 81.74 & 78.07 & 76.21 & 75.69 & 82.63 \\
\hline
\end{tabular}

Note: 1-9 - Kastek, lherzolite (sample. TS90-1x); 10-18 - Uchkuduk, harzburgite (sample TS90-5x).

rocks in diamondiferous diatremes [Sobolev, 1974]. The garnet typically contains elevated $\mathrm{Na}$ concentrations, which was confirmed by replicate analyses of the same samples at various Russian and Chinese laboratories.

All of the minerals except only for the orthopyroxene show no evidence of any influence of melt. The orthopyroxene is always surrounded by reaction rims of complicated composition, involving olivine.

The spinel-bearing olivine websterite and pyroxenite of the black suite compose a continuous rock series and exhibit the following distinguishing features:

(a) they have cumulus textures with growth zones of clinopyroxene (which is usually pale purple because of elevated concentrations of $\mathrm{TiO}_{2}$ of $0.52-0.57 \%$ and relatively low $\mathrm{Cr}_{2} \mathrm{O}_{3}$ of $0-0.18 \%$ );

(b) the Fe\# values of the rocks (20-35\%) and their mafic minerals $\left(f_{\mathrm{ol}}=18-20 \% ; f_{\mathrm{rpy}}=18 \%\right)$ are notably higher than in the green suite;

(c) the spinel is pleonast;

(d) one websterite nodule contained a xenolith of crystalline schist.

These facts testify that the xenoliths of the black suite are of magmatic genesis and that these xenoliths were captured by the alkaline basaltic magma during its ascent through the crust.

All black-suite xenoliths from the Kastek neck show traces of interstitial melting, which is pronounced in the development of cellular textures filled with glass and newly formed minerals. Studies of one of such domains indicate that a rim around aluminous orthopyroxene contains newly formed olivine and $\mathrm{K}-\mathrm{Na}$ feldspar.

The xenoliths of both the black and the green suites con- tain equilibrium orthopyroxene and clinopyroxene. Evaluations of the crystallization temperatures of these mineral assemblages by the method of $\mathrm{F}$. Boyd has not revealed any significant differences between them. Equilibrium pyroxene pairs yield crystallization temperatures of 900 to $970^{\circ} \mathrm{C}$ for the green suite and 870 to $940^{\circ} \mathrm{C}$ for the black one. The minimum temperature of $870^{\circ} \mathrm{C}$ was obtained for black-suite lherzolite with a cumulus texture.

\section{Ultramafic Nodules of the Uchkuduk Neck}

This locality, which was first documented in [Dobretsov et al., 1979, is situated approximately $15 \mathrm{~km}$ southwest of Issyk Kul Lake, where the Lower Carboniferous sedimentary rocks are cut by three limburgite stocks. The ultramafic nodules range from 1 to $10 \mathrm{~cm}$ across and are predominantly angular or, more rarely, rounded.

The contacts of the ultramafic nodules with the host basalt are toothed because of embayments of alkaline basaltic melt and because it enters the interstitial space of the nodules. Interaction between the melt and xenolith involves melting of the nodules and the development of purple Tiaugite rims around clinopyroxene grains in the nodule and cellular rims of partial melting around clinopyroxene.

The composition of these mantle nodules is notably different from that of nodules at Kastek: no spinel lherzolite was found among these nodules, which are dominated by wehrlite, websterite and clinopyroxenite (Figure 2). The bulk-rock compositions of the typical xenoliths and the composition of their rock-forming minerals are reported in Table 1 Table 6 
Table 3. Electron Microprobe Analyses (wt. \%) of Clinopyroxenes From the Kastek and Uchkuduk Xenoliths

\begin{tabular}{|c|c|c|c|c|c|c|c|c|c|}
\hline & 1 & 2 & 3 & 4 & 5 & 6 & 7 & 8 & 9 \\
\hline $\mathrm{SiO}_{2}$ & 52.25 & 51.60 & 52.07 & 52.01 & 51.10 & 50.85 & 50.05 & 51.97 & 52.10 \\
\hline $\mathrm{TiO}_{2}$ & 0.55 & 0.89 & 0.75 & 0.81 & 0.71 & 1.01 & - & 0.24 & 0.42 \\
\hline $\mathrm{Al}_{2} \mathrm{O}_{3}$ & 6.26 & 6.37 & 6.30 & 6.60 & 6.52 & 5.89 & 6.78 & 6.73 & 6.64 \\
\hline $\mathrm{FeOt}$ & 3.67 & 3.89 & 3.71 & 3.52 & 4.42 & 4.36 & 4.58 & 2.92 & 3.28 \\
\hline $\mathrm{MnO}$ & - & - & - & - & - & - & - & 0.21 & - \\
\hline $\mathrm{MgO}$ & 14.87 & 15.39 & 15.81 & 15.55 & 15.58 & 15.97 & 16.54 & 15.63 & 15.62 \\
\hline $\mathrm{CaO}$ & 21.07 & 20.73 & 20.57 & 20.46 & 20.40 & 20.39 & 20.53 & 19.78 & 19.66 \\
\hline $\mathrm{Na}_{2} \mathrm{O}$ & 1.30 & 1.12 & 0.85 & 1.07 & 1.25 & 1.19 & 1.29 & 1.94 & 1.62 \\
\hline $\mathrm{Cr}_{2} \mathrm{O}_{3}$ & - & - & - & - & - & - & - & 0.85 & 0.65 \\
\hline Wo & 44.85 & 4.92 & 43.76 & 43.73 & 42.70 & 42.35 & 41.56 & 41.67 & 41.94 \\
\hline En & 44.05 & 45.37 & 46.80 & 46.25 & 45.38 & 46.16 & 46.59 & 45.82 & 46.37 \\
\hline Fs & 6.09 & 6.42 & 6.17 & 5.88 & 7.18 & 7.02 & 7.12 & 5.12 & 5.45 \\
\hline Ac & 5.01 & 4.39 & 3.27 & 4.14 & 4.74 & 4.47 & 4.73 & 7.40 & 6.25 \\
\hline $\mathrm{Si}$ & 1.895 & 1.870 & 1.886 & 1.882 & 1.849 & 1.846 & 1.803 & 1.862 & 1.878 \\
\hline $\mathrm{Ti}$ & 0.015 & 0.024 & 0.020 & 0.022 & 0.019 & 0.028 & 0.000 & 0.006 & 0.011 \\
\hline $\mathrm{Al}$ & 0.162 & 0.272 & 0.269 & 0.282 & 0.278 & 0.252 & 0.288 & 0.284 & 0.282 \\
\hline $\mathrm{Fe}^{* *}$ & 0.104 & 0.101 & 0.100 & 0.100 & 0.062 & 0.049 & 1.500 & 0.001 & 0.064 \\
\hline $\mathrm{Fe}^{* * *}$ & 0.007 & 0.017 & 0.012 & 0.007 & 0.072 & 0.084 & 0.196 & 0.089 & 0.034 \\
\hline $\mathrm{Mg}$ & 0.804 & 0.832 & 0.854 & 0.839 & 0.841 & 0.865 & 0.888 & 0.835 & 0.842 \\
\hline $\mathrm{Ca}$ & 0.819 & 0.805 & 0.798 & 0.793 & 0.791 & 0.793 & 0.792 & 0.759 & 0.759 \\
\hline \multirow[t]{2}{*}{$\mathrm{Na}$} & 0.091 & 0.079 & 0.060 & 0.075 & 0.088 & 0.084 & 0.090 & 0.135 & 0.113 \\
\hline & 10 & 11 & 12 & 13 & 14 & 15 & 16 & 17 & 18 \\
\hline $\mathrm{SiO}_{2}$ & 51.96 & 51.68 & 52.44 & 50.43 & 50.17 & 49.83 & 48.61 & 50.02 & 50.81 \\
\hline $\mathrm{TiO}_{2}$ & 0.42 & 0.33 & 0.42 & 1.71 & 1.96 & 2.32 & 1.83 & 1.94 & 1.71 \\
\hline $\mathrm{Al}_{2} \mathrm{O}_{3}$ & 7.27 & 6.92 & 6.64 & 3.99 & 4.49 & 4.51 & 4.28 & 4.22 & 3.99 \\
\hline $\mathrm{FeOt}$ & 2.65 & 3.02 & 2.90 & 5.20 & 5.67 & 6.29 & 7.28 & 6.51 & 5.20 \\
\hline $\mathrm{MnO}$ & - & - & - & - & - & - & - & - & - \\
\hline $\mathrm{MgO}$ & 15.73 & 15.46 & 15.50 & 14.86 & 14.50 & 14.00 & 14.70 & 14.56 & 14.86 \\
\hline $\mathrm{CaO}$ & 19.57 & 19.49 & 19.36 & 23.03 & 23.24 & 23.10 & 22.67 & 22.73 & 23.03 \\
\hline $\mathrm{Na}_{2} \mathrm{O}$ & 1.61 & 2.30 & 1.74 & - & - & - & 0.69 & - & - \\
\hline $\mathrm{Cr}_{2} \mathrm{O}_{3}$ & 0.77 & 0.68 & 1.00 & - & - & - & - & - & 0.81 \\
\hline Wo & 42.14 & 41.03 & 41.78 & 48.21 & 48.57 & 48.63 & 46.49 & 47.31 & 48.23 \\
\hline En & 47.14 & 45.29 & 46.55 & 43.28 & 42.17 & 41.01 & 41.95 & 42.15 & 43.28 \\
\hline Fs & 4.45 & 4.91 & 4.88 & 8.51 & 9.26 & 10.36 & 11.57 & 10.54 & 8.49 \\
\hline $\mathrm{Ac}$ & 6.27 & 8.76 & 6.79 & - & - & - & - & - & - \\
\hline $\mathrm{Si}$ & 1.869 & 1.853 & 1.889 & 1.875 & 1.856 & 1.850 & 1.812 & 1.853 & 1.871 \\
\hline $\mathrm{Ti}$ & 0.011 & 0.009 & 0.011 & 0.048 & 0.055 & 0.065 & 0.051 & 0.054 & 0.047 \\
\hline $\mathrm{Al}$ & 0.308 & 0.292 & 0.282 & 0.175 & 0.196 & 0.197 & 0.188 & 0.184 & 0.173 \\
\hline $\mathrm{Fe}^{* *}$ & 0.058 & 0.033 & 0.078 & 0.162 & 0.175 & 0.195 & 0.141 & 0.201 & 0.160 \\
\hline $\mathrm{Fe}^{* * *}$ & 0.022 & 0.123 & 0.010 & 00 & 0 & 0.086 & 0.001 & 0 & \\
\hline $\mathrm{Mg}$ & 0.844 & 0.827 & 0.833 & 0.824 & 0.799 & 0.775 & 0.817 & 0.804 & 0.816 \\
\hline $\mathrm{Ca}$ & 0.754 & 0.749 & 0.747 & 0.917 & 0.921 & 0.919 & 0.905 & 0.902 & 0.909 \\
\hline $\mathrm{Na}$ & 0.112 & 0.160 & 0.122 & - & - & - & - & - & - \\
\hline
\end{tabular}

Note: 1-7 - Kastek, lherzolite (sample TS90-1-4x); 8-12 - the same, (sample. TS90-1x); 13-18 - Uchkuduk, harzburgite (sample TS90-5x).

The wehrlite is dark green massive rock of poikilitic texture, containing the assemblage $\mathrm{Cpy}+\mathrm{Ol}+\mathrm{Opx}+\mathrm{Pl}+\mathrm{Sp}$. The average grain size is $1.5 \mathrm{~mm}$, and the largest grains are $3.5 \mathrm{~mm}$. The rocks are poor in $\mathrm{Ti}$ and have $\mathrm{Fe} \#=21 \%$.

The clinopyroxene occurs as large grayish to greenish grains, sometimes with a discernible purplish tint, and is rich in $\mathrm{Ti}\left(1.1 \% \mathrm{TiO}_{2}\right)$ and poor in Fe Table 3 . The olivine forms euhedral to anhedral poikilitic ingrowths in clinopyroxene. The ore mineral is titanomagnetite and is mostly a secondary mineral, which was formed during recrystalliza- tion of analcime glass in contact with its inclusion.

The contacts of the ultramafic nodules with the host rock are scalloped because the alkaline basalt melt entered the interstitial space of the rocks of this nodule. Interaction between the melt and nodule is seen as the partial melting of the nodule material, development of purplish Ti-augite rim around clinopyroxene of the nodule, and growth of cellular rims of partial melting in clinopyroxene.

The wehrlite shows features that characterize this rock as intermediate between the peridotites of the green and black 
Table 4. Electron Microprobe Analyses (wt. \%) of Orthopyroxenes From the Kastek Xenoliths

\begin{tabular}{|c|c|c|c|c|c|c|c|c|c|}
\hline & 1 & 2 & 3 & 4 & 5 & 6 & 7 & 8 & 9 \\
\hline $\mathrm{SiO}_{2}$ & 55.09 & 54.95 & 57.09 & 55.01 & 55.09 & 55.41 & 55.65 & 55.05 & 55.00 \\
\hline $\mathrm{TiO}_{2}$ & - & - & 0.07 & - & - & 0.03 & - & - & - \\
\hline $\mathrm{Al}_{2} \mathrm{O}_{3}$ & 5.79 & 4.98 & 4.94 & 4.79 & 5.22 & 3.99 & 4.21 & 4.51 & 4.37 \\
\hline $\mathrm{FeOt}$ & 7.09 & 7.18 & 7.22 & 6.85 & 7.14 & 6.24 & 6.18 & 6.20 & 5.85 \\
\hline $\mathrm{MnO}$ & 0.10 & 0.08 & 0.16 & 0.04 & 0.05 & 0.04 & 0.09 & 0.07 & 0.10 \\
\hline $\mathrm{MgO}$ & 32.41 & 32.25 & 32.15 & 32.19 & 32.08 & 32.26 & 32.87 & 32.74 & 32.91 \\
\hline $\mathrm{CaO}$ & 0.68 & 0.69 & 0.72 & 0.73 & 0.70 & 0.58 & 0.51 & 0.63 & 0.78 \\
\hline $\mathrm{Na}_{2} \mathrm{O}$ & - & - & - & - & - & - & 0.06 & - & - \\
\hline $\mathrm{K}_{2} \mathrm{O}$ & 0.03 & - & 0.02 & - & 0.06 & - & 0.06 & 0.02 & 0.02 \\
\hline $\mathrm{Cr}_{2} \mathrm{O}_{2}$ & 0.50 & 0.23 & 0.33 & 0.15 & 0.33 & 0.19 & 0.12 & 0.23 & 0.30 \\
\hline Wo & 1.32 & 1.41 & 1.38 & 1.00 & 1.52 & 1.49 & 1.22 & 1.23 & 1.50 \\
\hline En & 87.78 & 87.35 & 87.62 & 89.44 & 89.41 & 89.77 & 90.50 & 89.18 & 88.20 \\
\hline Fs & 10.90 & 11.24 & 11.00 & 9.56 & 9.07 & 8.74 & 8.28 & 9.59 & 10.30 \\
\hline $\mathrm{Si}$ & 1.877 & 1.893 & 1.933 & 1.908 & 1.897 & 1.940 & 1.924 & 1.910 & 1.896 \\
\hline $\mathrm{Ti}$ & - & - & 0.002 & - & - & 0.001 & - & - & - \\
\hline $\mathrm{Al}$ & 0.233 & 0.202 & 0.197 & 0.196 & 0.212 & 0.165 & 0.172 & 0.184 & 0.178 \\
\hline $\mathrm{Cr}$ & 0.013 & 0.006 & 0.009 & 0.004 & 0.009 & 0.005 & 0.003 & 0.006 & 0.008 \\
\hline $\mathrm{Fe}^{* *}$ & 0.202 & 0.201 & 0.204 & 0.199 & 0.206 & 0.183 & 0.179 & 0.18 & 0.145 \\
\hline $\mathrm{Fe}^{* * *}$ & 0.006 & 00 & 00 & 0 & 0 & 0 & & & \\
\hline Mn & 0.03 & 0.002 & 0.005 & 0.001 & 0.001 & 0.001 & 0.003 & 0.002 & 0.029 \\
\hline $\mathrm{Mg}$ & 1.646 & 1.664 & 1.623 & 1.665 & 1.647 & 1.684 & 1.694 & 1.693 & 1.691 \\
\hline $\mathrm{Ca}$ & 0.025 & 0.025 & 0.026 & 0.027 & 0.026 & 0.022 & 0.019 & 0.023 & 0.029 \\
\hline $\mathrm{Na}$ & 0 & 0 & 0 & 0 & 0 & 0 & 0.004 & 0 & 0 \\
\hline $\mathrm{K}$ & 0.001 & 0 & 0.001 & 0 & 0.003 & 0 & 0.003 & 0.001 & 0.001 \\
\hline
\end{tabular}

suites. Considered together with the heterogeneity of the olivine and clinopyroxene composition (as was determined by G. L. Dobretsov) in the xenoliths of both the green and black suites, this led us to regard these rocks, together with the similar "green pyroxenites", as xenoliths of the so-called secondary upper mantle, which can reportedly be formed in relation to the ascent of its material, recrystallization, and partial melting.

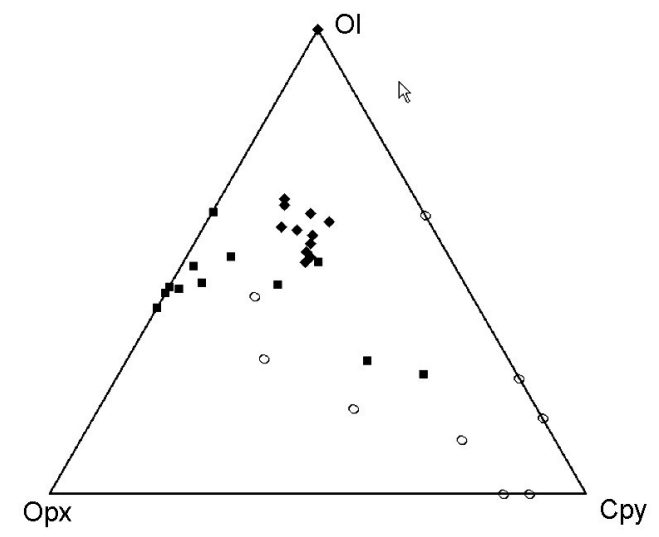

Figure 2. Ol-Opx-Cpy diagram for mantle xenoliths. Solid squares - xenoliths in the Kastek neck, open circles - xenoliths in the Uchkuduk neck (this publication), solid diamonds - xenoliths in the Toyun basalts [Zheng et al., 2006].
The olivine pyroxenite is a black massive rock consisting of clinopyroxene an variable contents of olivine (0-20\%) and ore mineral $(2-10 \%)$, which is responsible for the variability of the composition of the nodules in the clinopyroxenitewehrlite series. The Fe\# of the rocks is $28.3 \%$.

The clinopyroxene is purplish Ti-augite with growth zoning and hourglass structures, which testify (together with the occurrence of poikilitic olivine ingrowths) to the obviously cumulate texture of the rock. In contact with the host rock, a dark purple reaction rim of Ti-augite is formed. The melting of clinopyroxene at grain boundaries is associated with the chloritization of glass in the melting interstices and the transition of clinopyroxene into glass $+\mathrm{Opx}+\mathrm{Pl}$. Ore mineral occurs only in molten domains.

The structural features and compositional traits of the clinopyroxenite led us to suggest that these rocks are cumulates whose parental melts were derived via partial melting of primary mantle lherzolite material.

Ultramafic xenoliths in the Kastek and Uchkuduk necks can thus be classified into two clearly distinct groups: (i) xenoliths of the green suite and (ii) those of the black suite.

Reaction relations in ultramafic nodules in contact with the basalt melt are typical of rocks of this type. Olivine, the most refractory mineral, is only disintegrated into individual xenocrysts and is partly fused by the melt. The outermost margins of the clinopyroxene grains consist of typical spongy material, which was partly melted and developed both near 
Table 5. Electron Microprobe Analyses (wt. \%) of Spinels From the Kastek and Uchkuduk Xenoliths

\begin{tabular}{|c|c|c|c|c|c|c|c|c|c|}
\hline & 1 & 2 & 3 & 4 & 5 & 6 & 7 & 8 & 9 \\
\hline $\mathrm{SiO}_{2}$ & 0.55 & - & 0.69 & 0.43 & 0.62 & 0.07 & - & - & 0.60 \\
\hline $\mathrm{TiO}_{2}$ & - & - & - & 0.29 & - & 0.55 & 0.09 & - & - \\
\hline $\mathrm{Al}_{2} \mathrm{O}_{3}$ & 58.65 & 59.13 & 58.97 & 58.03 & 59.25 & 46.32 & 52.22 & 66.29 & 60.16 \\
\hline $\mathrm{FeOt}$ & 11.03 & 11.08 & 11.15 & 11.30 & 10.64 & 13.46 & 10.55 & 11.50 & 10.23 \\
\hline $\mathrm{MgO}$ & 19.87 & 20.44 & 19.86 & 19.93 & 19.90 & 35.16 & 21.27 & 21.61 & 19.62 \\
\hline \multirow[t]{2}{*}{$\mathrm{Cr}_{2} \mathrm{O}_{3}$} & 9.80 & 9.41 & 9.45 & 10.09 & 9.77 & 4.23 & 17.00 & 0.45 & 4.91 \\
\hline & 10 & 11 & 12 & 13 & 14 & 15 & 16 & 17 & 18 \\
\hline $\mathrm{SiO}_{2}$ & - & - & - & - & - & - & 0.03 & 0.06 & 0.07 \\
\hline $\mathrm{TiO}_{2}$ & - & - & - & - & - & - & 0.49 & 0.93 & 0.55 \\
\hline $\mathrm{Al}_{2} \mathrm{O}_{3}$ & 55.90 & 58.30 & 57.44 & 57.84 & 57.69 & 56.05 & 56.05 & 38.21 & 46.32 \\
\hline FeOt & 10.20 & 11.47 & 10.75 & 10.95 & 10.50 & 18.39 & 18.33 & 20.78 & 13.46 \\
\hline $\mathrm{MnO}$ & 0.06 & - & 0.11 & 0.12 & 0.07 & 0.25 & 0.25 & 0.21 & - \\
\hline $\mathrm{MgO}$ & 21.30 & 20.48 & 21.18 & 21.05 & 21.28 & 18.17 & 10.17 & 15.92 & 35.16 \\
\hline $\mathrm{Cr}_{2} \mathrm{O}_{3}$ & 12.43 & 9.22 & 9.84 & 9.93 & 9.65 & 6.37 & 6.37 & 24.01 & 4.23 \\
\hline
\end{tabular}

Note: 1-14 - Kastek (sample TS90-1x), 15-18 - Uchkuduk.

contact with the host rock and in the nodule. Orthopyroxene in contact with tephrite is always surrounded by double reaction rim $0.3-0.6 \mathrm{~mm}$ thick. The inner portion of the rim is cryptocrystalline, and the outer one consists of larger grains of olivine $(75 \%)$ and ore mineral $(3-5 \%)$ submerged in colorless glass of anorthoclase composition. The rims were reportedly formed during interaction between excess silica, which was produced by the incongruent melting of the orthopyroxene, with the residual liquid analcime phase of the tephrite, with the synthesis of anorthoclase.

The nodules of crustal rocks consist of metamorphic schists, granulites, anorthosites, and fragments of quartz and anorthoclase. These nodules were affected by the basaltoid melt and were partly melted and recrystallized. The melting of acid crustal xenoliths depends on their size and composition, and the products of this process range from quartz grains without any traces of melting and newly formed brown glass around plagioclase inclusions and skeletal plagioclase crystals to the complete dissolution of the anorthosites.

The model Sm-Nd isochron age of a lherzolite xenolith the Uchkuduk basalt is $2894 \pm 180 \mathrm{Ma}$, and the ${ }^{40} \mathrm{Ar} /{ }^{39} \mathrm{Ar}$ age of diopside in a lherzolite xenolith from the Kastek neck (sample TS-90-1/5) is $2593 \pm 141 \mathrm{Ma}$. As of now, these are the oldest age values for the continental mantle in Asia. At the same time, an augite megacryst in basalt from the Kastek neck has an ${ }^{40} \mathrm{Ar} /{ }^{39} \mathrm{Ar}$ age of $610 \mathrm{Ma}$.

Previously we have already attracted attention to the fact that basalts in the North Tien Shan are strongly degassed, and their ${ }^{3} \mathrm{He} /{ }^{4} \mathrm{He}$ ratios normalized to the atmo-

Table 6. Electron Microprobe Analyses (wt. \%) of Garnets From the Kastek Xenoliths

\begin{tabular}{|c|c|c|c|c|c|c|c|c|c|}
\hline & 1 & 2 & 3 & 4 & 5 & 6 & 7 & 8 & 9 \\
\hline $\mathrm{SiO}_{2}$ & 40.08 & 39.75 & 40.88 & 41.54 & 39.83 & 39.42 & 43.56 & 41.43 & 43.49 \\
\hline $\mathrm{TiO}_{2}$ & - & - & - & - & - & - & 0.04 & - & 0.02 \\
\hline $\mathrm{Al}_{2} \mathrm{O}_{3}$ & 22.79 & 23.40 & 23.92 & 25.75 & 24.09 & 23.12 & 24.43 & 25.59 & 27.53 \\
\hline $\mathrm{FeOt}$ & 11.19 & 10.83 & 8.79 & 7.28 & 10.55 & 11.33 & 8.67 & 9.82 & 8.75 \\
\hline $\mathrm{MnO}$ & - & - & - & - & - & - & 0.23 & 0.10 & 0.06 \\
\hline $\mathrm{MgO}$ & 21.09 & 21.78 & 19.10 & 17.40 & 20.76 & 22.51 & 18.36 & 9.70 & 7.17 \\
\hline $\mathrm{CaO}$ & 4.80 & 4.21 & 6.16 & 6.74 & 4.71 & 3.56 & 5.69 & 10.96 & 9.31 \\
\hline $\mathrm{Na}_{2} \mathrm{O}$ & - & - & 1.10 & 1.25 & - & - & - & 0.69 & 1.95 \\
\hline $\mathrm{K}_{2} \mathrm{O}$ & - & - & - & - & - & - & 0.05 & 0.22 & 0.68 \\
\hline $\mathrm{Cr}_{2} \mathrm{O}_{3}$ & - & - & - & - & - & - & - & 0.13 & 0.24 \\
\hline Py & 68.44 & 68.89 & 67.12 & 66.09 & 69.06 & 71.64 & 66.90 & 41.92 & 38.09 \\
\hline Alm & 20.37 & 19.84 & 17.32 & 15.51 & 19.68 & 20.22 & 17.72 & 23.80 & 26.07 \\
\hline Gr & 11.19 & 11.23 & 15.56 & 18.40 & 11.26 & 8.14 & 14.90 & 34.04 & 35.54 \\
\hline $\mathrm{Sp}$ & - & - & - & - & - & - & 0.48 & 0.25 & 0.30 \\
\hline
\end{tabular}


Table 7. He-Ar Isotopes $\left(10^{-6} \mathrm{~cm}^{3} / \mathrm{g}\right)$ of Ultramafic Xenoliths and Enclosed Basalt [ Grachev, 1999

\begin{tabular}{|c|c|c|c|c|c|c|c|}
\hline $\mathrm{N}$ & Sample & Rock, mineral & Weight, $\mathrm{g}$ & ${ }^{4} \mathrm{He}$ & ${ }^{3} \mathrm{He} /{ }^{4} \mathrm{He}$ & ${ }^{40} \mathrm{Ar}$ & ${ }^{40} \mathrm{Ar} /{ }^{36} \mathrm{Ar}$ \\
\hline \multicolumn{8}{|c|}{ Xenoliths } \\
\hline \multicolumn{8}{|c|}{ Uchkuduk } \\
\hline 1 & TS-90-5 & Sp.Lhr & 1.4519 & 0.18 & $2.4 \pm 0.1$ & 0.51 & $1372 \pm 25$ \\
\hline 2 & TS-90-5 & $\mathrm{Ol}$ & 1.1016 & 0.21 & $2.5 \pm 0.1$ & 0.50 & $300 \pm 2$ \\
\hline 3 & TS-90-5 & $\mathrm{Ol}^{*}$ & 1.549 & 0.22 & $2.9 \pm 0.3$ & - & - \\
\hline 4 & TS-90-5 & $\mathrm{Ol}$ & 0.4330 & 0.15 & $10.0 \pm 3.0$ & 0.22 & $318 \pm 7$ \\
\hline 5 & TS-90-5 & $\mathrm{Ol}$ & 1.3851 & 0.0095 & $58 \pm 6$ & 0.12 & $325 \pm 7$ \\
\hline 6 & TS-90-5 & $\mathrm{Py}$ & 1.0442 & 0.025 & $22 \pm 2$ & 0.21 & $338 \pm 6$ \\
\hline \multicolumn{8}{|c|}{ Kastek } \\
\hline 7 & TS-91-1 & $\mathrm{Ol}$ & 1.0577 & 0.0235 & 28 & nd & nd \\
\hline 8 & TS-91-1 & Rpy & 0.7613 & 0.07 & 11.7 & nd & nd \\
\hline 9 & TS-91-1 & Ti oxide & 0.4309 & 0.091 & 5.0 & nd & nd \\
\hline 10 & TS-90-1/4 & gabbro & 0.8580 & 0.24 & $1.8 \pm(-0.2)$ & 0.61 & $354 \pm 5$ \\
\hline \multicolumn{8}{|c|}{ Basalts } \\
\hline \multicolumn{8}{|c|}{ Uchkuduk } \\
\hline 11 & TS-90-5 & limburgite & 0.7673 & 4.8 & $0.05 \pm 0.005$ & 6.1 & $1500 \pm 10$ \\
\hline 12 & TS-90-5 & $"$ & 0.7668 & 4.5 & $0.045 \pm 0.01$ & 5.5 & $1550 \pm 15$ \\
\hline 13 & TS-90-5 & $"$ & 0.3410 & 4.7 & 0.02 & 5.7 & $1245 \pm 15$ \\
\hline 14 & TS-90-1 & basalt & 0.7097 & 3.9 & $0.11 \pm 0.02$ & 3.4 & $1455 \pm 15$ \\
\hline 15 & TS-90-1 & $"$ & 0.5366 & 4.4 & $0.073 \pm 0.015$ & 5.6 & $1070 \pm 10$ \\
\hline \multicolumn{8}{|c|}{ Kastek } \\
\hline 16 & TS-90-1 & basalt & 0.7097 & 3.90 & $0.11 \pm 0.02$ & 3.4 & $1455 \pm 15$ \\
\hline 17 & TS-90-1 & $"$ & 0.5366 & 4.40 & $0.073 \pm 0.01$ & 5.6 & $1070 \pm 10$ \\
\hline 18 & TS-90-1/5 & $\mathrm{Amph}^{* *}$ & 0.5209 & 0.53 & $1.5 \pm 0.1$ & 5.1 & $1690 \pm 10$ \\
\hline 19 & TS-91-1 & $\mathrm{Ol}^{* *}$ & 0.5574 & 0.226 & $3.1 \pm 0.3$ & nd & nd \\
\hline 20 & TS-91-1 & Cpy** & 0.7273 & 0.212 & $2.9 \pm 0.3$ & nd & nd \\
\hline 21 & TS-90-1 & basalt $* * *$ & 2.0 & 1.0 & 0.85 & nd & nd \\
\hline
\end{tabular}

Note: $*$ - after leaching $\mathrm{HNO}_{3}, * *-$ megacrysts, $* * *$ - crushing; nd - not.

spheric value of $R_{\mathrm{a}}\left(R_{\mathrm{a}}=1.39 \times 10^{-6}\right)$ varies from $0.04 R_{\mathrm{a}}$ to $1.1 R_{\mathrm{a}}$ for basalts in the Uchkuduk neck to $2.2 R_{\mathrm{a}}$ for basalts in the Kastek neck (Table 7) [Grachev, 1999].

Mantle xenoliths in the Uchkuduk and Kastek necks yield principally different He isotopic parameters. The $R / R_{\text {a }}$ ratio of the former ranges from 1.7 to 4.7 at an almost unchanging ${ }^{3} \mathrm{He}$ concentration, which testifies to a cosmogenic nature of this isotope. This is explained by the fact that the Uchkuduk neck is deeply eroded and its material was bombarded by cosmic radiation during a time span of at least 30 Ma.

Conversely, the Kastek neck is weakly eroded, and its most fully exposed portions were intersected by four excavations, and $25 \mathrm{~kg}$ of ammonite were installed in them and blasted. This made it possible to collect xenolith samples that originally occurred at depths of 1 to $2 \mathrm{~m}$.

Assuming that the exposure time of rocks in the Kastek neck is close to $1 \mathrm{Ma}$ (which is an period of time undoubtedly longer than the time span during which erosion exposed these rocks, considering the young age of the valley of the Karakastek River, no older than 200-300 ka, judging from the age of its terraces), it is possible to evaluate the effect of cosmic radiation.

The productivity of cosmogenic He is controlled by the elevation above sea level and geographic latitude [Lal, 1991.
Staudacher and Allegre, 1991. By analogy with evaluations for such areas as the Vitim Plateau at the Baikal rift and the Taryat depression in Mongolia, whose altitudes and latitudes are comparable with those of Kastek Range, the maximum productivity of ${ }^{3} \mathrm{He}_{\text {cosm }}$ is close to $1.98 \times 10^{-17} \mathrm{~cm}^{3} / \mathrm{g}$ annually [Staudacher and Allegre, 1991], the total amount of spallogenic He generated during a time span of $1 \mathrm{Ma}$ is estimated at $0.2 \times 10^{-12} \mathrm{~cm}^{3} / \mathrm{g}$. Hence, the ${ }^{3} \mathrm{He} /{ }^{4} \mathrm{He}$ ratio of olivine from a xenolith in basalt form the Kastek neck (sample TS91-1, Table 7) is, with regard for ${ }^{3} \mathrm{He}_{\mathrm{cosm}}, R / R_{0}=14.4$, which is obviously higher than the value typical of a source of the MORB type and testifies to a contribution of a plume component [Kaneoka, 1998]. Strictly speaking, it was not necessary to introduce this correction for the xenolith from the Kastek neck, because the samples were not collected at the surface but taken from a depth of more than $1 \mathrm{~m}$.

It is worth mentioning that traces of fluid enriched in mantle $\mathrm{He}\left({ }^{3} \mathrm{He} /{ }^{4} \mathrm{He} \geq 10^{-5}\right)$ were found in gases in groundwaters of the North Tien Shan [Polyak et al., 1989, 1990] and outline the same territory of the Tien Shan as that with Cretaceous-Paleogene basalt containing mantle xenoliths.

Along with the Kastek and Uchkuduk necks, mantle xenoliths were also found in Cretaceous-Paleogene basalts in the Toyun Basin in the southern part of the Tien Shan, at the 


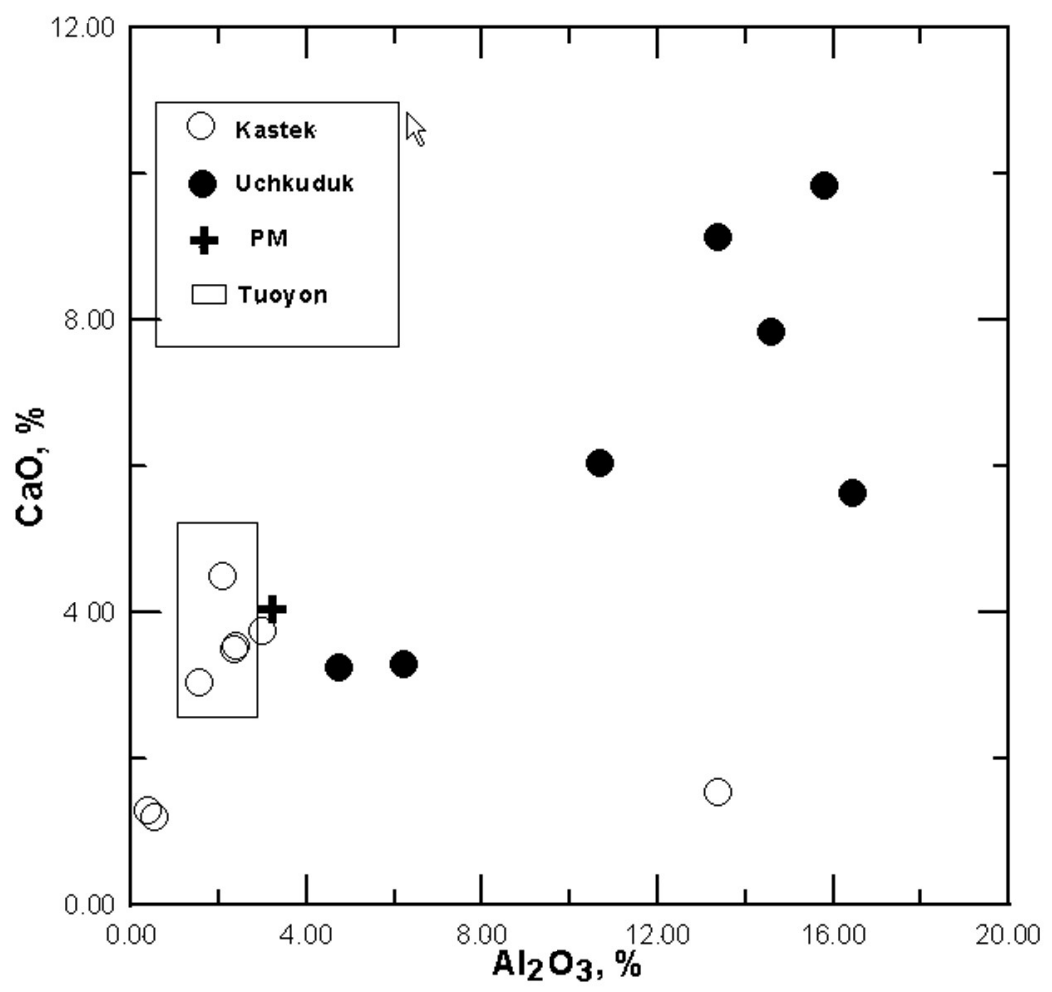

Figure 3. $\mathrm{CaO}-\mathrm{Al}_{2} \mathrm{O}_{3}$ diagram for mantle xenoliths. $\mathrm{PM}$ - primitive mantle according to [Zindler and Hart, 1986. Rectangle - compositions of xenoliths in the Toyun basalts [Zheng et al., 2006].

boundary with the Tarim Massif. Back in the late 19th century, K. I. Bodganovich found mafic magmatic rocks in this area, hosted in Cretaceous and Paleogene sedimentary rocks [Gapeeva, 1949]. These rocks were later dated by Ar isotopic techniques at 67-46 Ma [Sobel and Arnaud, 2000]. Rocks in the bottom portion of the basalt pile in the Toyun area at the southeastern termination of the Talas-Fergana Fault contain xenoliths of spinel lherzolite, along with pyroxenite and granulite and with amphibole, pyroxene, and anorthoclase megacrysts [Zheng et al., 2006]. Analogous xenoliths were found in spinel lherzolite xenoliths in basalt in the Ortosu area in the Kyrgyz Republic northeast of Toyun [Bagdassarov et al., 2011. Egorova et al., 2009 (Figure 1.

\section{Discussion and Conclusions}

Nowadays information is available on the composition of the upper mantle at three sites in the North Tien Shan, with these sites occurring on a north-south line and are spaced approximately $300 \mathrm{~km}$ apart. The aforementioned information testifies that the local mantle is laterally heterogeneous: its composition is lherzolite in the northern and southern parts and predominantly pyroxenite at the latitude of the Issyk-Kul depression (in the vicinity of the Uchkuduk neck).

The Ol-Opx-Cpy and $\mathrm{CaO}-\mathrm{Al}_{2} \mathrm{O}_{3}$ diagrams Figure 2 and Figure 3 show similarities between the compositions of the mantle beneath the Kastek Range in the northern Tien Shan and in the Toyun-Ortosu area in the south, in contrast to the pyroxenite mantle in the Uchkuduk area. An analogous conclusion follows from the chondrite-normalized REE patterns (Figure 4, Table 8) of the rocks, which demonstrate a similarity of mantle composition beneath the Kastek Range and that of the primitive mantle. Data on the Nd and Sr iso-

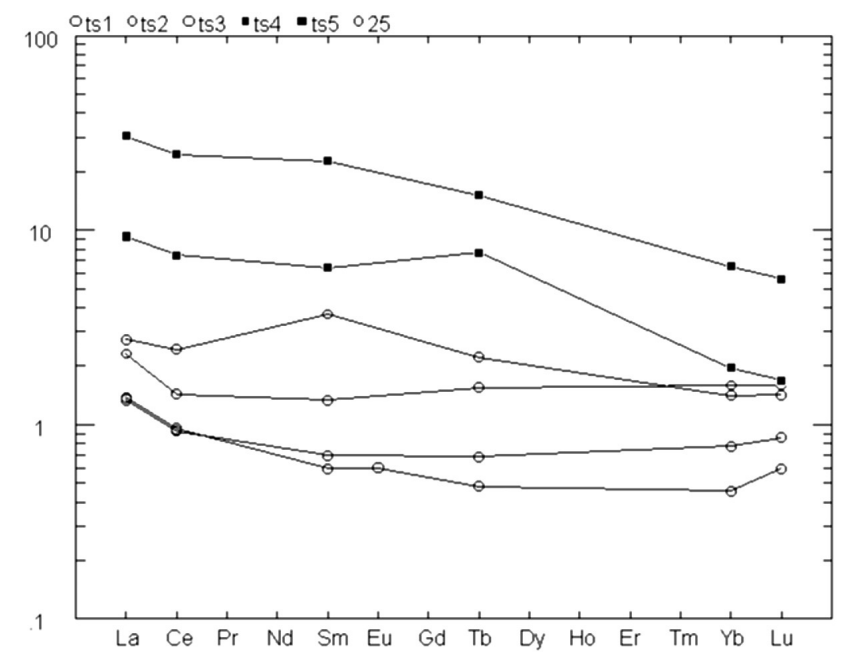

Figure 4. REE pattern for ultrabasic xenoliths, normalized to chondrite after Sun 1982: open circles - Kastek xenoliths, closed circles - Uchkuduk xenoliths. 


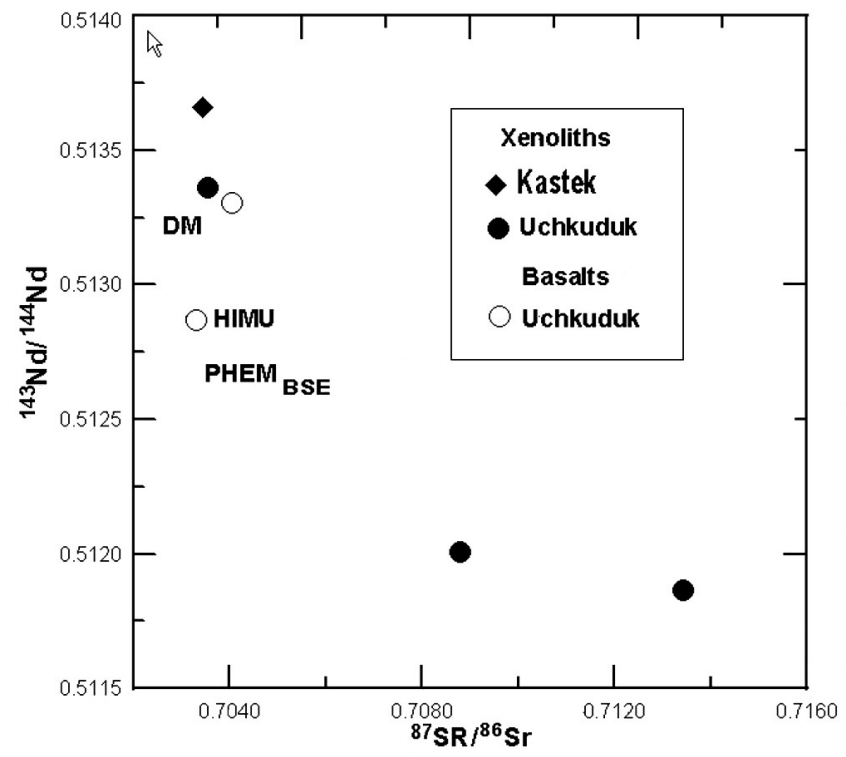

Figure 5. Nd-Sr diagram for mantle xenoliths and their host basalts. Solid squares - xenoliths in the Kastek neck, open circles - xenoliths in the Uchkuduk neck (this publication), solid diamonds - xenoliths in basalts [Sobel and Arnaud, 2000.

topic composition Table 9 and Figure 5 provide evidence of two distinct mantle reservoirs beneath the Tien Shan: enriched mantle beneath the area of the Uchkuduk neck and depleted mantle beneath Kastek.

The time when the lateral heterogeneity of the mantle underneath the North Tien Shan was produced can be inferred from the age of the host basalts, whose median K-Ar age is $55 \mathrm{Ma}$ [Grachev, 1999]. As was earlier inferred from a complex of geochemical features of the basalts, they were generated under the effect of a mantle plume [Grachev, 1999 . Sobel and Arnaud, 2000, which affected an area as large as $300,000 \mathrm{~km}^{2}$. However, unlike other manifestations of plume magmatism (such flood basalts in Siberian and the Deccan Plateau), basalt sheets in the Tien Shan are no thicker than a few dozen meters, and hence, the total volume of the erupted lavas is lower than in eastern Siberia and the Deccan Plateau [Grachev, 2000].

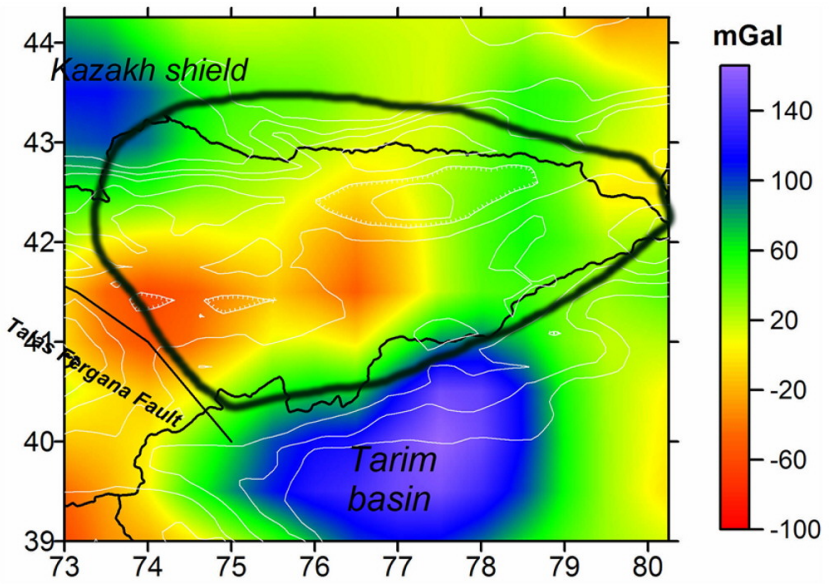

Figure 6. Mantle gravity anomalies obtained upon subtracting the effect of the crust from the observed gravity field (prepared by M. K. Kaban). The black contour shows the boundaries of the field of the Cretaceous-Paleogene basalts.

It is well known that plume magmatism induces, due to underplating processes, significant changes in the lithospheric structure and results in a high-velocity layer in the bottom part of the crust (Hawaii, Iceland, Deccan, and eastern Siberia) [Grachev, 2000 Grachev and Kaban, 2006]. It is important to mention that the heterogeneities induced by plume magmatism in the structure of the lithosphere are preserved for dozens [Bjarnason et al., 1993. Charvis et al., 1995 Darbyshire et al., 1998 or even hundreds of million years, as is the case, for example, with eastern Siberia [Grachev and Kaban, 2006]. As was demonstrated earlier, the most significant velocity heterogeneities beneath the North Tien Shan occur immediately beneath the Moho, with up to $3 \%$ decrease in the velocities of seismic waves relative to the average values [Vinnik, 1998], as is typical of areas with magmatic underplating.

Based on the comparative analysis of newly obtained gravity data and seismic models constructed with the application of the receiver function technique [Kosarev et al., 1993. Vinnik, 2004, Vinnik et al.,2004, an area of lower density was outlined in the North Tien Shan. Figure 6 displays mantle gravity anomalies obtained upon subtracting the effect of the crust from the observed gravity field. Thereby

Table 8. The Average Content of REE (ppm) in the Cenozoic Basalts and Deep-Derived Xenoliths of North Tien Shan

\begin{tabular}{lcccccccccc}
\hline & $1(4)$ & $2(9)$ & $3(3)$ & $4(2)$ & $5(3)$ & $6(3)$ & $7(1)$ & $8(2)$ & $9(4)$ & $10(3)$ \\
\hline $\mathrm{La}$ & 33.2 & 32.2 & 45.0 & 41.0 & 0.44 & 0.76 & 0.90 & 3.05 & 10.05 & 34.3 \\
$\mathrm{Ce}$ & 65.7 & 59.7 & 79.0 & 77.0 & 0.80 & 1.24 & 2.1 & 6.4 & 21.2 & 62 \\
$\mathrm{Sm}$ & 6.8 & 6.9 & 10.6 & 8.8 & 0.14 & 0.27 & 0.75 & 1.3 & 4.6 & 5.4 \\
$\mathrm{~Tb}$ & 0.82 & 0.98 & 1.2 & 1.5 & 0.034 & 0.077 & 0.11 & 0.38 & 0.75 & 0.87 \\
$\mathrm{Yb}$ & 0.99 & 1.6 & 2.1 & 1.8 & 0.17 & 0.35 & 0.31 & 0.43 & 1.43 & 2.2 \\
$\mathrm{Lu}$ & 0.13 & 0.23 & 0.26 & 0.27 & 0.029 & 0.054 & 0.048 & 0.057 & 0.19 & 0.34 \\
$\mathrm{La} / \mathrm{Yb}$ & 255.4 & 140 & 173 & 152 & 15.2 & 14.1 & 18.7 & 53.5 & 52.9 & 100.9 \\
\hline
\end{tabular}

Note: 1 - basanites of neck Kastek, 2 - dolerites in the Cenozoic rocks of Boom canyon, 3 - basalts in the Cenozoic rocks of Bailamtal mountains, 4 - basanites of Uchkuduck neck, 5-10 - deep-seated xenoliths in basanites of Kastek and Uchkuduck necks: 5 - harzburgite of the green series, 6 - spinel lherzolite of the green series, 7 - spinel-olivine websterite of the green series, 8 - wehrlite of the black series, 9 - pyroxenite of the black series, 10 - anorthosite of the lower crust. 

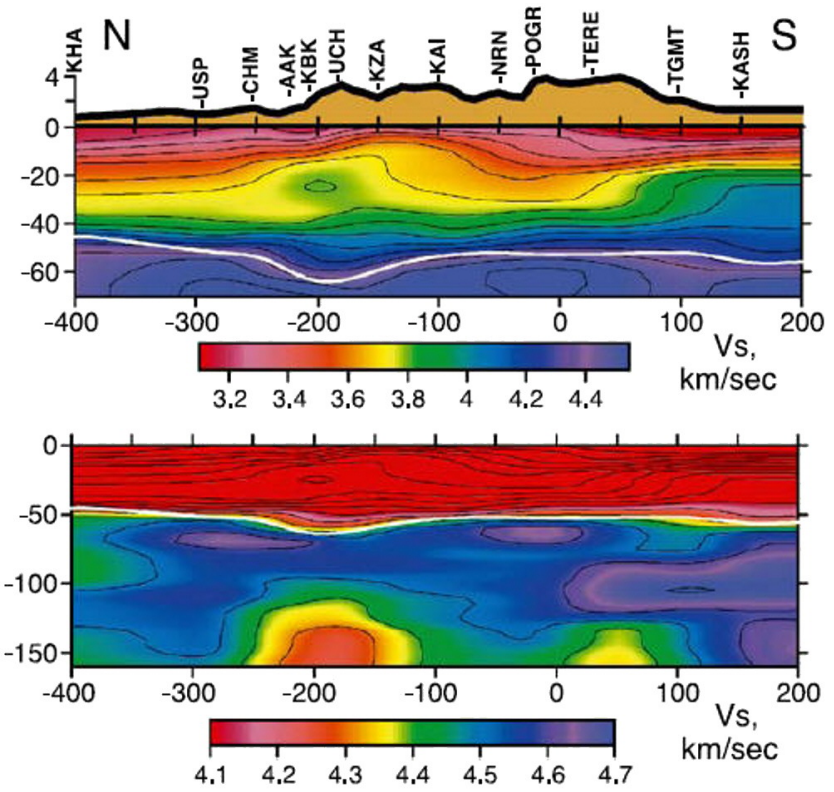

Figure 7. Cross-section of the $S$ velocity model along the line in Figure 1 for the crust (top) and for the crust and mantle (bottom) [Vinnik et al., 2004]. Topography along the line is shown at the top. The stations are from the corridor $\pm 50 \mathrm{~km}$ wide.

the following three important points should be stressed:

1. the contours of the area of lower density coincide with the field of the plume Cretaceous-Paleogene basalts;

2. the area of lower density also corresponds to lower crustal thicknesses;

3. mantle xenoliths of wehrlite-pyroxenite composition in the Uchkuduk neck (spot 2 in Figure 1) occur in the zone of lower density mantle (Figure 6), whereas the lherzolite mantle in the Kastek and Toyun-Ortosu areas (spots 1, 3, and 4) lies outside the area with lower density mantle.
The mineralogy of xenoliths from Uchkuduk, partial melting and recrystallization zones in them, and their enrichment in LREE were produced during the melting of the primary lherzolite mantle in relation to a pressure decrease during the ascent of a mantle plume. Metasomatic transformations of this type result in a lower density of the mantle material, which is, in turn, reflected in the seismic structure of this portion of the North Tien Shan.

According to seismic tomography data [Vinnik et al., 2004 , the Uchkuduk area has the lowest velocities of S-waves in the upper mantle $\left(V_{s}<4.4 \mathrm{~km} / \mathrm{s}\right.$ at depths from 110 to $130 \mathrm{~km}$ ) (Figure 7 and Figure 8) (NB: Using the multiple regression to relate $\mathrm{Vp}$ to $\mathrm{SiO}_{2}$ and $\mathrm{MgO}$ for igneous rocks under confining pressures from 0.6 to $1.0 \mathrm{Gpa}$ [Kelemen, Holbrook, 1995 and taking into account the correction for the temperature at crust-mantle boundary $\left(\sim 400^{\circ} \mathrm{C}\right)$, using $d v_{p} / d T$ of $0.0005 \mathrm{~km} / \mathrm{s} /{ }^{\circ} \mathrm{C}$ [Christenesen, 1979], the average $V_{p}$ values for Uchkuduk xenoliths are significantly less than for Kastek ones). We believe that this anomaly in $V_{s}$ provides evidence that the area hosts the now-crystalline head part of a mantle plume. Tomographic sections through the local crust (sites $\mathrm{KBK}, \mathrm{UCH}$, and KZA in the upper portion of Figure 7 also clearly show a high-velocity layer in the bottom part of the crust, as is typical of the lithosphere in areas of plume magmatism [Bjarnason et al., 1993. Charvis et al., 1995 Darbyshire et al., 1998 Grachev and Kaban, 2006. The high-velocity layer in the bottom of the crust tapers northward in the area of Site KHA (Figure 7) outside the field of plume basalts.

Our data on the compositional traits of the local mantle obtained by studying the mineralogy and geochemistry of mantle xenoliths in basalts allowed us to explain the variations in the density heterogeneities identified by seismic tomography techniques and gravity field simulations. The modern structure of the lithosphere beneath the North Tien Shan was shaped by the activity of a mantle plume at $55 \mathrm{Ma}$ in a pre-rifting environment. The subsequent orogenesis in the earliest Neogene in response to the collision of the Eurasian and Indian lithospheric plates affected only the uppermost structural stages, whereas the deep structure of the

Table 9. Sm-Nd and Rb-Sr Isotopes of Ultramafic Xenoliths and Basalts of North Tien-Sahn

\begin{tabular}{lccccccccc}
\hline $\mathrm{N}$ & Sample & $\mathrm{Sm} *$ & $\mathrm{Nd}{ }^{*}$ & $\mathrm{Rb}{ }^{*}$ & $\mathrm{Sr}{ }^{*}$ & ${ }^{147} \mathrm{Sm} /{ }^{144} \mathrm{Nd}$ & ${ }^{143} \mathrm{Nd} /{ }^{144} \mathrm{Nd}+2 \sigma$ & ${ }^{86} \mathrm{Rbr} / \mathrm{Sr}$ & ${ }^{87} \mathrm{Sr} /{ }^{86} \mathrm{Sr}$ \\
\hline 1 & TS-90-5, bas. & 3.021 & 12.64 & 16.84 & 830.7 & 0.14442 & $0.513305 \pm 16$ & 0.05862 & $0.70404 \pm 14$ \\
2 & TS-90-5, bas. & 26.95 & 37.00 & 17.47 & 846.6 & & $0.512872 \pm 11$ & 0.05965 & $0.70331 \pm 20$ \\
3 & TS-90-6, bas. & 37.77 & 41.50 & & & & $0.512906 \pm 24$ & \\
4 & TS-90-1, bas. & & & 38.37 & 1145.3 & & & 0.09700 & $0.70468 \pm 15$ \\
5 & TS-90-1, Rpy & 0.964 & 1.113 & 0.139 & 16.50 & 0.52345 & $0.513660 \pm 53$ & 0.02440 & $0.703448 \pm 38$ \\
6 & TS-90-5, Cpy & 1.140 & 2.316 & 0.507 & 51.11 & 0.29762 & $0.513362 \pm 41$ & 0.02869 & $0.703535 \pm 72$ \\
7 & TS-90-5, Rpy & 0.033 & 0.075 & 1.057 & 0.956 & 0.26199 & $0.512009 \pm 150$ & 3.19869 & $0.708786 \pm 254$ \\
8 & TS-90-5, Ol & 0.010 & 0.027 & 0.368 & 0.367 & 0.14442 & $0.511865 \pm 115$ & 2.90618 & $0.713428 \pm 440$ \\
\hline
\end{tabular}

Note: $\mathrm{Sm}, \mathrm{Nd}, \mathrm{Rb}$ and $\mathrm{Sr}$ concentrations in ppm (isotope dilution, precision is about $0.5 \%$ ), error estimations on ${ }^{147} \mathrm{Sm} /{ }^{144} \mathrm{Nd}$ and ${ }^{87} \mathrm{Rb} /{ }^{86} \mathrm{Sr}$ are $\pm 0.3 \%$ and $0.5 \%$ respectively. During the period of analytical work the weighted mean of 10 La Jolla Nd standart runs yielded $0.511852 \pm 4(2 \sigma)$, using 0.241579 for ${ }^{143} \mathrm{Nd} /{ }^{144} \mathrm{Nd}$ to normalize; and NBS-987 standard yeilded $0.710255 \pm 15(2 \sigma)$, using 8.375210 for ${ }^{87} \mathrm{Sr} /{ }^{86} \mathrm{Sr}$ to normalize. Total procedure blanks for $\mathrm{Nd}$ and $\mathrm{Sm}$ are 0.08 and $0.03 \mathrm{ng}$ respectively, and for Sr and $\mathrm{Rb}$ are 0.3 and $0.4 \mathrm{ng}$ respectively. All isotopic analyses were carried out on the Finningan MAT-261 solid source machine under multicollector static mode. Chemical preparation of rock samples and elements separation were done using standart procedure similar to [Richard et al., 1976 in the Precambrian Geolody and Geochemistry Institute (St. Petersburg). 


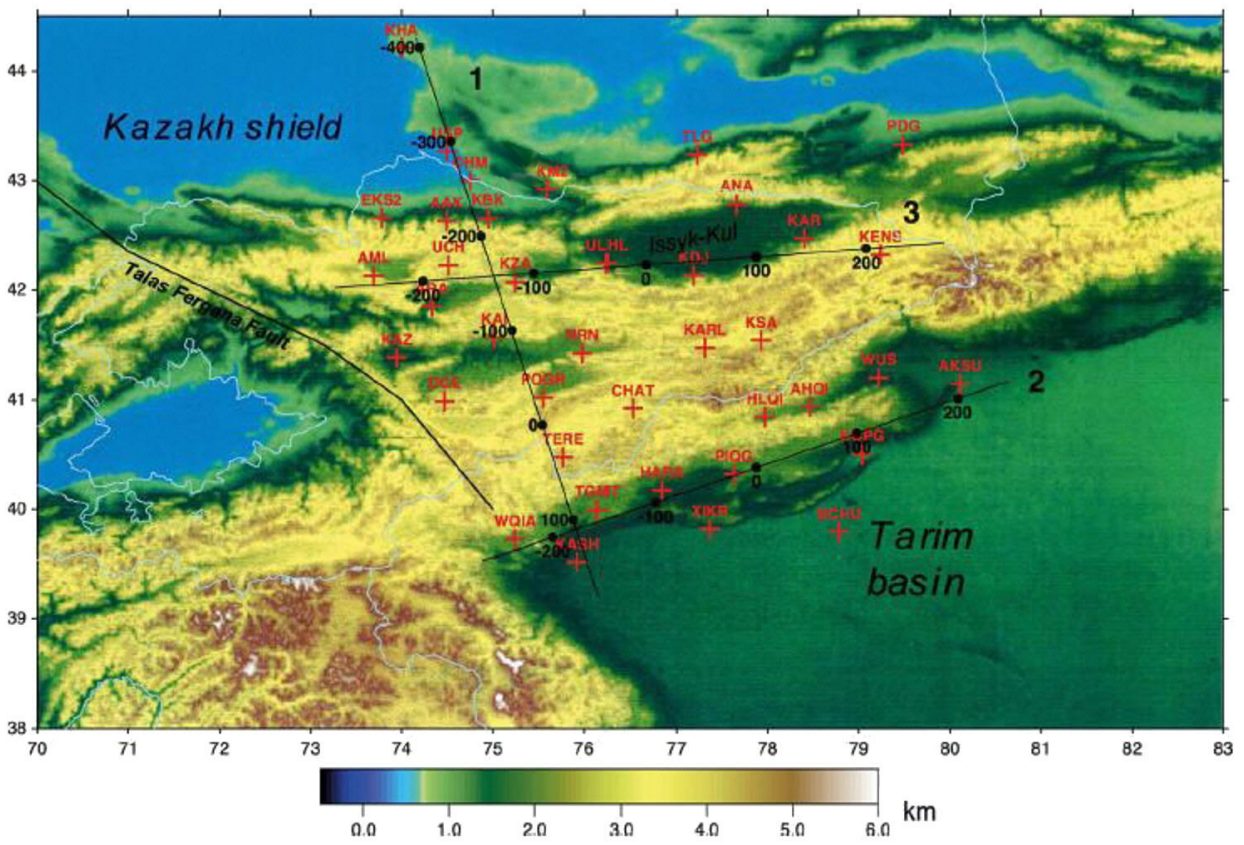

Figure 8. Map of the North Tien Shan with seismograph stations (red crosses). Straight lines are the profiles of the $S$ velocity sections [Vinnik et al., 2004].

lithosphere was inherited from that as of the latest Cretaceous.

In this context, it is pertinent to mention that the estimated crustal shortening in the course of orogenesis [Chediya, 1998 Yakovlev and Yunga, 2001 and analysis of seismic [Thomas et al., 1993 and paleomagnetic data [Bazhenov and Mikolaichuk, 2002, 2004 testify that the part of the Tien Shan east of the Talas-Fergana fault (i.e., in the field of plume magmatism) was much less affected by the collision of Eurasian and Indian lithospheric plates than other orogenic belts in Middle Asia.

\section{References}

Bagdassarov, N., V. Batalev, and V. Egorova (2011), State of lithosphere beneath Tien Shan from petrology and electrical conductivity of xenoliths, J. Geoph. Res., 116, B01202, doi $10.1029 / 2009 J B 007125$.

Bazhenov, M. L., and A. V. Mikolaichuk (2002), Paleomagnetism of Paleogene basalts from the Tien Shan, Kyrgyzstan: rigid Eurasia and dipole geomagnetic field, Earth Planet. Sci. Lett., 195, 155-166, doi 10.1016/S0012-821X(01)00586-6.

Bazhenov, M. L., and A. V. Mikolaichuk (2004), Structural evolution of Central Asia to the North of Tibet: A synthesis of paleomagnetic and geological data, Geotectonics, 38, 379-393.

Bjarnason, I. Yh., W. Menke, O. G Flovenz, and D. Caress (1993), Tomographic image of the Mid-Atlantic Plate boundary in South Western Iceland, J. Geophys. Res., 98, 6607-6622, doi $10.1029 / 92$ JB02412.

Charvis, Ph., M. Recq, St. Operato, and D. Brefort (1995), Deep structure of the northern Kergulen Plateau and hotspot-related activity, Geophys. J. Int., 122, 899-924, doi 10.1111/j.1365246X.1995.tb06845.x.
Chediya, O. K. (1998), Central Asia, noveishaya tektonika Severnoi Evrazii (Neotectonics of North Eurasia), Moscow, Geos, $52-57$.

Christensen, N. I. (1979), Compressional wave velocities in rocks at high temperature and pressures, critical thermal gradients, and crustal low-velocity zones, J. Geophys. Res., 84, 68496857, doi 10.1029/JB084iB12p06849

Darbyshire, F. A., I. Th. Bjarnoson, R. White, and O. G. Flovenz (1998), Crustal Structure above the Iceland Mantle Plume Imaged by ICEMELT Refraction Profile, Geophys. J. Int., 135, 1131-149, doi 10.1046/j.1365-246X.1998.00701.x

Dobretsov, G. L., and T. G. Dobretsova (1974), Deep Inclusions in Basaltoids and Alkaline Gavvroids of Kazakhstan and North Tien Shan, Glubinnye vklyucheniya $v$ kimberlitakh i problema sostava verkhnei mantii (Deep Inclusions in Kimberlites and the Problem of the Upper Mantle Composition), Novosibirsk, Nauka, 118-125.

Dobretsov, G. L., V. V. Kepezhinkas, V. V. Knauf, and L. V. Usova (1979), Ultramafic inclusions in limburgites of North Tien Shan and the problem of upper mantle pyroxenites, Geol. Geofiz., 3, 65-77.

Egorova, V., V. Batalev, V. Simonov, N. Bagdassarov, and Yu. Litasov (2009), Mineral chemistry and thermobarometry of peridotite xenoliths from Central Tien Shan basalts. Geophysical Research Abstracts, 11, EGU2009-7646.

Ermolov, P. V., and Wang Yifen (1997), Petrology of analcime microdolerites and deep xenoliths in the Radchenko neck, Geology of Kazakhstan, 3, 67-75.

Gapeeva, G. M. (1949), Toyun Camptonites, South Tien Shan, Zap. Vses. Mineral. O-va, 78, 1.

Gapeeva, G. M. (1951), Toyun Bekinkinite, South Tien Shan, Zap. Vses. Mineral. O-va, 80, 1.

Gliko, A. O., and A. F. Grachev (1987), On the Origin of Deep Processes Responsible for the Development of Intraplate Magmatism Areas and Continental Rifts, Dokl. Akad. Nauk SSSR, 295, no. 1, pp. 64-67.

Gliko, A. O., A. F. Grachev, and V. A. Magnitsky (1985), Thermal Model for Lithospheric Thinning and Associated Uplift in the Neotectonic Phase of Intraplate Orogenic Activity and 
Continental Rifts, J. Geodyn., 3, 137-153, doi 10.1016/02643707(85)90025-0

Grachev, A. F. (1989), Heterogeneity of the continental lherzolite mantle estimated from the ultrabasic xenoliths study, Physics and Interior Structure of the Earth (in Russian), Nauka, Moscow, 22-43.

Grachev, A. F. (1999), Early Cenozoic Magmatism and Geodynamics of North Tien Shan, Physics of the Solid Earth, 35, 815-839.

Grachev, A. F. (2000), Mantle plumes and problems of geodynamics, Physics of the Solid Earth, 36, 263-294.

Grachev, A. F., and M. K. Kaban (2006), Factors Responsible for the High Position of the Siberian Platform. Physics of the Solid Earth, 42, 987-998.

Ikorsky, S. V., and I. L. Kamensky (1998), Crushing technique of rocks and minerals in glass in a glass ampoule under the noble gases study, Abstracts of the 15 Symposium of isotope geochemistry, Moscow, 115.

Kamensky, I. L., I. N. Tolstichin, and V. R. Vetrin (1990), Juvenile helium in ancient rocks: ${ }^{3} \mathrm{He}$ excess in amphibolites from 2.8 Ga charnokite series - crust mantle fluid in intracrustal magmatic processes, Geochim. Cosmochim. Acta, 54, 3115-3122, doi 10.1016/0016-7037(90)90127-7

Kaneoka, I. (1998), Noble gas signatures in the Earth's interior coupled or decoupled behavior among each isotope systematics and problems related to their implication, Chem. Geol., 147, 61-76, doi 10.1016/S0009-2541(97)00172-1

Kelemen, P. B., and W. S. Holbrook (1995), Origin of thick, highvelocity igneous crust along the U.S. Coast Margin, J. Geophys. Res., 100, 10077-10094, doi 10.1029/95JB00924.

Kosarev, G. L., N. V. Petersen, L. P. Vinnik, and S. W. Roecker (1993), Receiver functions for the Tien Shan analog broadband network: contrasts in the evolution of structures across the Talasso-Fergana fault, J. Geophys. Res., 98, 4437-4448, doi $10.1029 / 92 J B 02651$

Lal, D. (1991), Cosmic ray labeling of erosion surfaces: in situ nuclide production rates and erosion models, Earth Planet. Sci. Lett., 104, 424-439, doi 10.1016/0012-821X(91)90220-C

Polyak, B. G., E. M. Prasolov, I. L. Kamenskii, N. M. Elmanova, A. A. Sultankhodzhaev, and I. G. Chernov (1989), He, Ne, and Ar Isotope Composition of Underground Fluids in Tien Shan, Geokhimiya, 1, 87-98.

Polyak, B. G., I. L. Kamenskii, A. A. Sultankhodzhaev, I. G. Chernov, L. N. Barabanov, A. K. Lisitsyn, and M. V. Khabarovskaya (1990), Sub-Mantle Helium in South Tien Shan Fluids, Dokl. Akad. Nauk SSSR, 312, 1, 721-725.

Radchenko, A. I. (1995), Diamond-bearing basaltoids in the Kastekskii Range, Geology and Exploration in Kazakhstan, 3 46-50.

Richard, P., N. Shimuzu, and C. J. Allegre (1976), ${ }^{143} \mathrm{Nd} /{ }^{144} \mathrm{Nd}$ a natural tracer. An application to oceanic basalts, Earth Planet. Sci. Lett., 31, 269-378, doi 10.1016/0012-821X(76)90219-3

Simonov, V. A., A. V. Mikolaichuk, S. V. Rasskazov, and S. V. Kovyazin (2008), Cretaceous-Paleogene within-plate magmatism in Central Asia: data from the Tien Shan basalts, Russian Geol- ogy and Geophysics, 49, 520-533, doi $10.1016 /$ j.rgg.2008.06.009

Sobel, E. R., and N. Arnaud (2000), Cretaceous-Paleogene basaltic rocks of the Tuyon basin, NW China and the Kyrgyz Tian Shan: the trace of a small plume, Lithos, 50, 191-215, doi 10.1016/ S0024-4937(99)00046-8

Sobolev, N. V. (1974), Deep-Seated Inclusions and Problem of the Upper Mantle Composition, Novosibirsk, Nauka, 264.

Staudacher, Th., and C. J. Allegre (1991), Cosmogenic neon in ultramafic nodules from Asia and in quartzite from Antarctica, Earth Plan. Sci. Lett., 106, 87-102, doi:10.1016/0012821X(91)90065-P

Sun, S. S. (1982), Chemical composition and origin of the Earth's primitive mantle, Geochim. Cosmochim. Acta, 46, 179-192, doi 10.1016/0016-7037(82)90245-9

Thomas, J.-C., H. Perroud, P. R. Cobbold, M. L. Bazhenov, V. S. Burtman, A. Chauvin, and E. Sadybakasov (1993), A Paleomagnetic Study of Tertiary Formations From the Kyrgyz Tien-Shan and Its Tectonic Implications, J. Geophys. Res., 98 9571-9589, doi 10.1029/92JB02912

Vinnik, L. P. (1976), Issledovaniya Mantii Zemli Seismicheskimi Metodami (Seismic Studies of the Earth's Mantle), Moscow, Nauka.

Vinnik, L. (2004), S receiver functions and a new generation of mantle models, Geoph. Res. Abstracts, 6, 04991.

Vinnik L., Ch. Reigber, I. M. Aleshin, G. l. Kosarev, M. K. Kaban, S. I. Oreshin, and S. W. Roecker (2004), Receiver function tomography of the central Tien Shan, Earth Planet. Sci. Lett., 225, 131-146.

Vinnik, L. P., A. M. Saiipbekova, and F. N. Yudakhin (1998), Deep-Structure and Dynamics of the Tien Shan Lithosphere, Dokl. Akad. Nauk SSSR, 268, 143-146.

Wang, Yifen, and P. V. Ermolov (1992), The petrogenesis of Karakastek basanite in Kazakhstan, Advances in Geosciences, 2, 179-188.

Yakovlev, F. L., and S. L. Yunga (2001), Crustal shortening during mountain building: A case study in the Pamir-Tien Shan and Altay-Mongolia region, Russian J. Earth Sci., 3, 317-332, doi $10.2205 / 2001 \mathrm{ES} 000072$

Zheng, J. P., et al. (2006), The lithospheric mantle beneath the southwestern Tienshan area, Contrib. Mineral. Petrol., 151, 457-479, doi 10.1007/s00410-006-0071-x

Zindler, A., and S. Hart (1986), Chemical Geodynamics, Ann. Rev. Earth Planet. Sci., 14, 493-571, doi 10.1146/annurev.ea. 14.050186.002425

P. V. Ermolov, Institute of Complex Development of Mineral Resources of the National Academy of Kazakhstan, 5 Ippodromnaya st., Karaganda, 470060, the Republic of Kazakhstan

A. F. Grachev, Institute of Physics of the Earth, Russian Academy of Sciences, 10 Bolshaya Gruzinskaya, Moscow, Russia. (afgrachev@gmail.com)

Wang Yifen, Institute of Geology, Academy Sinica, Beijing, 